\title{
Assimilation of bacteria by the dwarf surf clam Mulinia lateralis (Bivalvia: Mactridae)
}

\author{
Kashane Chalermwat, Timothy R. Jacobsen, Richard A. Lutz \\ Rutgers University, Institute of Marine and Coastal Sciences, Shellfish Research Laboratory, PO Box 678, Port Norris, New \\ Jersey 08349, USA
}

\begin{abstract}
Estimation of assimilation efficiency of bivalves, fed with radiolabeled bacteria, differs substantially depending on choice of tracer. We have investigated assimilation of bacteria by the dwarf surf clam Mulinia lateralis (Say) using bacteria labeled with either L- $\left[{ }^{35} \mathrm{~S}\right]$-methionine or $\left[\right.$ methyl- $\left.{ }^{3} \mathrm{H}\right]-$ thymidine. Labeled bacteria were fed to $M$. lateralis $6.18 \pm 0.45 \mathrm{~mm}$ (mean $\pm \mathrm{SD}$ ) in shell length in static pulse-chase experiments. After feeding and 4 consecutive $1 \mathrm{~h}$ chases in $0.2 \mu \mathrm{m}$ filtered seawater, M. Lateralis retained $93.34 \pm 6.45 \%(\mathrm{n}=20)$ of incorporated ${ }^{35} \mathrm{~S}$-methionine radioactivity. Alternatively, when ${ }^{3} \mathrm{H}$-thymidine was used, only $51.40 \pm 16.54 \%(\mathrm{n}=13)$ was retained. During our chase procedure, excretion patterns also differed conspicuously. For excreted ${ }^{35} \mathrm{~S}$ activity, $49.05 \pm 13.30 \%$ was recovered in the particulate phase $(>0.2 \mu \mathrm{m})$ and $50.94 \pm 13.30 \%$ was dissolved. The corresponding values for excreted ${ }^{3} \mathrm{H}$ were $11.43 \pm 4.70 \%$ and $88.57 \pm 4.70 \%$. Assimilation efficiency, estimated using ${ }^{35} \mathrm{~S}$ methionine, is considerably higher than previously reported values using ${ }^{14} \mathrm{C},{ }^{3} \mathrm{H}$ and ${ }^{15} \mathrm{~N}$ tracers. We can explain assimilation and excretion differences between tracers in terms of metabolic pathways associated with the labeled moieties. The assimilation of methionine and high retention of ${ }^{35} \mathrm{~S}$ tracer demonstrates the role of bacteria as a source of proteins and mineral nutrients for $M$. lateralis.
\end{abstract}

\section{INTRODUCTION}

The dwarf surf clam Mulinia lateralis (Say) is a common bivalve that inhabits soft substrata and exhibits high growth and reproduction rates. Opportunistic species such as $M$. lateralis increase dramatically in numbers under favorable conditions and can become dominant in benthic communities (Levinton 1970, Santos \& Simon 1980). Over short time periods, M. lateralis may attain local average densities of up to 21000 ind. $\mathrm{m}^{-2}$ (Santos \& Simon 1980). Elevated filtration and metabolic rates suggest that $M$. lateralis is adapted to exploit high food concentrations (Shumway 1983, Shumway \& Newell 1984). The possibility that food resources may seasonally fall below the energy requirements of $M$. lateralis, and the inability to catabolize protein reserves during starvation, may account for the mass mortalities that characterize this species (Shumway \& Newell 1984).

It is conceivable that suspended bacteria may constitute a food source for Mulinia lateralis in its natural habitat. The ability of bivalves to utilize bacteria has been verified by many authors (reviewed by Langdon \& Newell 1990). Effective clearance of free-living and natural-sized bacteria has been demonstrated by Wright et al. (1982), Lucas et al. (1987), and Langdon \& Newell (1990). Kemp et al. (1990) have shown that small- (shell height $=16 \mathrm{~mm})$ to large $-(40 \mathrm{~mm})$ sized individuals of the ribbed mussel Geukensia demissa (Dillwyn) can filter bacteria-sized particles with differing efficiency. The assimilation of both free-living and particle-bound bacteria (not necessarily natural bacterioplankton) has been demonstrated by Birkbeck \& McHenery (1982), Harvey \& Luoma (1984), Amouroux (1986), and Crosby et al. (1990). In addition to clearance and assimilation studies, the presence of bacteriolytic enzymes has been confirmed in bivalves by McHenery et al. (1979), Seiderer et al. (1984), and Jamieson \& Wardlaw (1989).

Many researchers studying feeding and assimilation of bacteria by suspension-feeding bivalves have utilized isotopic tracers to label bacteria. These studies have included the use of ${ }^{3} \mathrm{H}$-thymidine (Hollibaugh et al. 1980, Birkbeck \& McHenery 1982), ${ }^{14} \mathrm{C}$-glutamic acid (Amouroux 1986), ${ }^{14} \mathrm{C}$-[u]-D glucose (Harvey \& Luoma 1984, Crosby et al. 1990) and $\left[{ }^{15} \mathrm{~N}\right]$-ammonium sulfate (Crosby et al. 1990). In this study, we investigated the ability of Mulinia lateralis to assimilate a mixed assemblage of bacterioplankton using ${ }^{35} \mathrm{~S}$-methionine in comparison with ${ }^{3} \mathrm{H}$-thymidine as tracers.

The goal of our study was 2-fold: (1) to investigate 
the ability of $M$. lateralis to assinnilate bacterioplankton, and (2) to compare assimilation efficiency estimations obtained by using 2 isotopic tracers to label different macromolecules. The amino acid ${ }^{35} \mathrm{~S}$-methionine labels bacterial protein and has been used in trophic studies by Wikner et al. (1986). The sulfur in methionine plays an important structural role in intracellular proteins and functions as part of important coenzymes in enzyme reactions (Linder 1985). The tracer ${ }^{3} \mathrm{H}$-thymidine labels bacterial DNA and was originally proposed for trophic studies by Hollibaugh et al. (1980). Under certain circumstances, however, ${ }^{3} \mathrm{H}-$ thymidine may label other bacterial cellular components (see Hollibaugh 1988). Few tracer studies have been addressed towards differential utilization of bacterial macromolecules. We hypothesized that assimilation efficiency estimates would vary depending on the metabolic pathways associated with the different tracers.

\section{MATERIALS AND METHODS}

The specimens of Mulinia lateralis used in our experimental procedures were raised at the Rutgers Shellfish Research Laboratory, New Jersey, USA. Specimens were maintained in flow-through containers and fed daily with algae batch-cultured in Kalwall $^{\mathrm{TM}}$ tubes. Experimental organisms averaged 6.18 $\pm 0.45 \mathrm{~mm}$ in shell length (mean $\pm \mathrm{SD}, \mathrm{n}=33$ ). Experiments were conducted at room temperature $\left(24.0 \pm 0.5^{\circ} \mathrm{C}\right.$ ) in sterile tissue culture wells (Falcon, 3.6 $\mathrm{ml}$ capacity). Bivalves were maintained in $0.45 \mu \mathrm{m}$ filtered seawater for 6 to $8 \mathrm{~h}$ before being used in experiments. During that period, if bivalves defecated, the water was changed. A Tracor Analytic Mark III, Model 6881 LSC, was used for scintillation counting. Radioactivity measurements in disintegrations per minute (dpm) were corrected for quenching and counting efficiency using external standards to establish a quench curve.

Our experimental protocol consisted of 3 steps: (1) isolation of bacteria and radioisotope labeling; (2) pulse-feeding; and (3) chase, which includes purging of residual radioactivity and excretion.

Bacteria isolation and labeling. Bacterial assemblages used in this study were obtained from Tahitian Isochrysis aff. galbana Green (strain T-ISO) cultures raised in Kalwall ${ }^{\mathrm{TM}}$ tubes. Bacteria were separated from algae by filtration through $47 \mathrm{~mm}$ diameter, $1 \mu \mathrm{m}$ pore size polycarbonate filters (vacuum $<20 \mathrm{kPa}$ ). After separation, bacteria were counted by the acridine orange direct count method (AODC) developed by Hobbie et al. (1977). Subsamples of $100 \mu \mathrm{l}$ were taken from the stock and 10 random fields per filter were enumerated under oil immersion. Bacterioplankton present in 50 to $60 \mathrm{ml}$ of the bacterial suspension were caught on $47 \mathrm{~mm}$ diameter, $0.2 \mu \mathrm{m}$ pore size polycarbonate filters. They were then washed (10 ml, $0.45 \mu \mathrm{m}$ filtered seawater) and resuspended by shaking (1 $\mathrm{min}$ ) in $50 \mathrm{ml}$ polypropylene centrifuge tubes with $5 \mathrm{ml}$ of $0.45 \mu \mathrm{m}$ filtered seawater (salinity $22 \mathrm{ppt}$ ). Additional seawater was added to the initial volume. Bacteria were counted after resuspension by AODC to determine percentage recovery. Resuspended bacteria were subsequently incubated in $50 \mathrm{ml}$ sterile plastic bags (Whirl-Pak) in subdued light with either L- $\left[{ }^{35} \mathrm{~S}\right]-$ methionine (specific activity $=1134$ $\mathrm{Ci} \mathrm{mmol}{ }^{-1}$, final conc. $=0.002 \mathrm{nmol} \mathrm{ml^{-1 }} ; \mathrm{NEN}$ Research Products) or [methyl ${ }^{35} \mathrm{H}$ ]-thymidine (specific activity $=2.0 \mathrm{Ci} \mathrm{mmol}^{-1}$, final conc. $=11.25 \mathrm{nmol}$ $\mathrm{ml}^{-1}$ ). Bacteria were incubated in ${ }^{35} \mathrm{~S}$-methionine for $60 \mathrm{~min}$; incubation time for ${ }^{3} \mathrm{H}$-thymidine was either 30,60 or $120 \mathrm{~min}$ depending on rate of ${ }^{3} \mathrm{H}$-thymidine uptake. We used ${ }^{35} \mathrm{~S}$-methionine to label bacterial protein (Wikner et al. 1986) and ${ }^{3} \mathrm{H}$-thymidine to label bacterial DNA (Hollibaugh et al. 1980; see also Hollibaugh 1988).

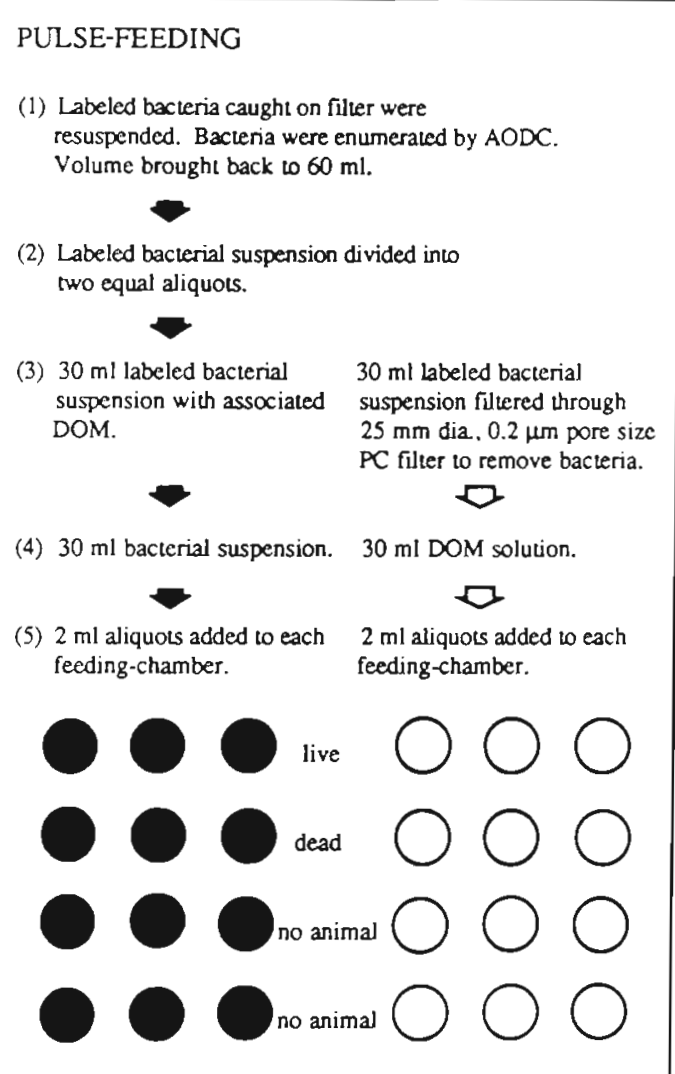

Fig. 1. Protocol for pulse-feeding Mulinia lateralis with labeled bacteria in tissue culture wells. AODC: acridine orange direct count method; DOM: dissolved organic matter; PC: polycarbonate 
Pulse-feeding. After incubation, labeled bacteria were collected on $47 \mathrm{~mm}$ diameter, $0.2 \mu \mathrm{m}$ polycarbonate filters and rinsed twice with $5 \mathrm{ml}$ each of $0.45 \mu \mathrm{m}$ filtered seawater to remove unincorporated label. Bacteria were then resuspended as described above. Bacteria were counted again (AODC) to estimate percentage, recovery and degree of clumping.

The resulting resuspended bacteria were used for feeding and assimilation studies. Bacterial concentrations added to feeding chambers ranged from 4.0 to $8.5 \times 10^{6}$ cells $\mathrm{ml}^{-1}$. Radioactivity in the bacterial suspension was determined for particles caught on $0.2 \mu \mathrm{m}$ pore size filters.

Preliminary experiments indicated that some label from bacteria was released during our resuspension procedure. Therefore, prior to feeding experiments, the labeled bacterial suspension was divided into 2 equal portions (Fig. 1). One portion was filtered through a $25 \mathrm{~mm}$ diameter, $0.2 \mu \mathrm{m}$ pore size polycarbonate filter to remove bacteria. The filtrate was collected in acidwashed and combusted glass scintillation vials. This filtrate was used for dissolved-phase uptake controls. Each experimental run consisted of 2 replicate sets of feeding chambers. One set was used for bacteria plus associated dissolved organic matter (DOM), the other for DOM only. Each set consisted of at least 12 chambers: 6 wells with bivalves (usually 3 live and 3 formalin-killed) and 6 wells without. For each chamber, 2 ml of suspension (bacteria + DOM or DOM only) was added. Suspensions were added to empty wells as controls for label disappearance resulting from feeding-chamber wall adsorption. Radioactivity in 3 wells without bivalves were sampled at the beginning of the experiment. The 3 remaining no-bivalve wells were sampled after $1 \mathrm{~h}$. The difference in activity was used to correct uptake values.

Feeding was carried out in a laminar flow hood under continuous lighting. Bivalves were allowed to feed for $1 \mathrm{~h}$, after which they were removed and placed in new sterile wells. Remaining radioactivity was assayed by taking $1 \mathrm{ml}$ samples from each well. Samples were assayed in $7 \mathrm{ml}$ plastic MiniVials with $5 \mathrm{ml}$ ScintiVerse LC cocktail.

Chase. In the chase procedure, live bivalves incubated with both bacteria and DOM, and with DOM only, were blotted dry and placed in new culture wells with $2 \mathrm{ml}$ of $0.2 \mu \mathrm{m}$ filtered seawater. After each $1 \mathrm{~h}$ incubation (total $4 \mathrm{~h}$ ), bivalves were removed from the wells, blotted dry, and transferred to new wells. Radioactivity excreted in wells was assayed by filtering each well's total volume through $25 \mathrm{~mm}$ diameter, 0.2 $\mu \mathrm{m}$ polycarbonate filters. Particles caught on each filter were washed with a total of $3 \mathrm{ml}$ of $0.45 \mu \mathrm{m}$ filtered seawater and assayed (particulate excretion). Filtrate from each well $(1 \mathrm{ml})$ was assayed separately for dissolved excretion.
After termination of the chase procedure, bivalves were blotted dry, placed in scintillation vials, and digested in Scintigest tissue solubilizer for $24 \mathrm{~h}$ at $60^{\circ} \mathrm{C}$. After digestion, the shells were removed with fine forceps and $35 \mu \mathrm{l}$ glacial acetic acid was added to the digestion mixture to decrease chemiluminescence. Tissue dpm values were corrected for variable quench and for self-absorption. The pulse-chase experiments were repeated 6 times for ${ }^{35} \mathrm{~S}$-methionine and 3 times for ${ }^{3} \mathrm{H}$ thymidine, using different batches of bacteria.

Added radioactivity. Radioactivity added in particulate phase $\left(R_{\mathrm{p}}\right)$ was calculated by subtracting dissolved (filtrate) radioactivity $\left(R_{\mathrm{d}}\right)$ from total radioactivity in stock bacterial suspension $\left(R_{(\mathrm{p}+\mathrm{d})}\right)$

$$
R_{\mathrm{p}}=R_{(\mathrm{p}+\mathrm{d})}-R_{\mathrm{d}}
$$

Incorporated radioactivity. Incorporated particulate radioactivity $\left(I R_{\mathrm{p}}\right)$ was calculated by subtracting radioactivity remaining in dissolved set $\left(R R_{\mathrm{d}}\right)$ from total remaining radioactivity in wells $\left(R R_{(\mathrm{p}+\mathrm{d})}\right)$ and subtracting this remaining $\mathrm{dpm}$ value from added particulate radioactivity:

$$
I R_{\mathrm{p}}=R_{\mathrm{p}}-\left(R R_{(\mathrm{p}+\mathrm{d})}-R R_{\mathrm{d}}\right)
$$

Isotope excretion. For each experimental set, excreted radioactivity was obtained by subtracting excreted radioactivity from treatment controls (dissolved) from corresponding total excretion values.

Particulate excretion: For calculation of particulate phase excretion we used the following formula:

$$
E P R_{\mathrm{p}}=E P R_{(\mathrm{p}+\mathrm{d})}-E P R_{\mathrm{d}}
$$

where $E P R_{\mathrm{p}}=$ excreted particulate radioactivity from particulate uptake; $E P R_{(\mathrm{p}+\mathrm{d})}=$ excreted particulate radioactivity from total uptake; and $E P R_{\mathrm{d}}=$ excreted particulate radioactivity from dissolved uptake.

Dissolved excretion: For calculation of dissolved phase excretion resulting from particulate uptake we used the formula:

$$
E D R_{\mathrm{p}}=E D R_{(\mathrm{p}+\mathrm{d})}-E D R_{\mathrm{d}}
$$

where $E D R_{\mathrm{p}}=$ excreted dissolved radioactivity from particulate uptake $E D R_{(\mathrm{p}+\mathrm{d})}=$ excreted dissolved radioactivity from total uptake; and $E D R_{\mathrm{d}}=$ excreted dissolved radioactivity from dissolved uptake.

Total excretion: Cumulative excretion (particulate phase and dissolved phase) after $4 \mathrm{~h}$ was calculated as:

$$
\sum E R_{\mathrm{p}}=\sum E P R_{\mathrm{p}}+\sum E D R_{\mathrm{p}}
$$

where $\sum E R_{\mathrm{p}}=$ total excreted radioactivity from particulate uptake after 4 chases, $\sum_{E P R_{\mathrm{p}}}=$ particulate excretion from particulate uptake after 4 chases, and $\sum E D R_{\mathrm{p}}=$ dissolved excretion from particulate uptake after 4 chases. 
Assimilation efficiency. Assimilation efficiency $(A E)$ was calculated as:

$$
A E=\frac{I R_{\mathrm{p}}-\sum E R_{\mathrm{p}}}{I R_{\mathrm{p}}} \times 100
$$

\section{RESULTS}

Preliminary clearance studies showed that within $1 \mathrm{~h}$ Mulinia lateralis could clear $33.48 \pm 5.50 \%$ of bacterial cells from suspension. Incubation of bacteria with isotopes did not noticeably alter size or appearance of cells. We observed no clumping of bacteria after resuspension. The recovery of bacteria from filters ranged from 50 to $100 \%$ (mean $77 \%$ ).

Uptake of particulate radioactivity by clams was variable for both isotopes and was apparently related to activity of the organisms during feeding. An average of $74.92 \pm 18.54 \%$ of methionine was taken up (range = 19.05 to 94.82 ), whereas the corresponding value for thymidine was $49.51 \pm 15.28 \%$ (range $=19.88$ to 69.60).

Average tracer radioactivity present in bivalve tissue (assimilation) after digestion and scintillation counting was within $5 \%$ of values obtained by subtraction (Table 1). Assimilation estimates reported in this study were obtained by subtraction.

The discrepancy in tracer Ietention is shown graphically in Fig. 2. Assimilated radioactivity values, expressed as percentage of incorporated radioactivity, after 4 chases were $93.34 \pm 6.45(\mathrm{n}=20)$ for ${ }^{35} \mathrm{~S}$ methionine and $51.40 \pm 16.54(\mathrm{n}=13)$ for ${ }^{3} \mathrm{H}$-thymidine. Retention of incorporated ${ }^{35} \mathrm{~S}$ was higher than that of ${ }^{3} \mathrm{H}$ from the beginning of the chase period.

The difference between particulate and dissolved fractions of excreted radioactivity, in relation to time,

Table 1. Mulinia lateralis. Label activity remaining in tissue from digestion and scintillation counting, compared to values obtained by subtraction of excreted radioactivity. Experiments with ${ }^{35} \mathrm{~S}$-methionine were run 6 times. Experiments with ${ }^{3} \mathrm{H}$ thymidine were run 3 times. Average $M$. lateralis ${ }^{35} \mathrm{~S}$ background dpm $=49 \pm 7(n=18):{ }^{3} \mathrm{H}$ background dpm $=176 \pm$ $42(\mathrm{n}=9)$; Subtr.: subtraction; Scint.: scintillation

\begin{tabular}{|c|c|c|c|c|c|c|}
\hline & \multicolumn{3}{|c|}{${ }^{35} \mathrm{~S}$-methionine } & \multicolumn{3}{|c|}{${ }^{3} \mathrm{H}$-thymidine } \\
\hline & \multicolumn{2}{|c|}{ Mean dpm } & \multirow{2}{*}{$\mathrm{n}$} & \multicolumn{2}{|c|}{ Mean dpm } & $\mathrm{n}$ \\
\hline & Subtr. & Scint. & & Subtr. & Scint. & \\
\hline & 89150 & 85531 & 3 & 10694 & 10029 & 3 \\
\hline & 205659 & 172284 & 5 & 7277 & 6937 & 4 \\
\hline & 407586 & 400417 & 3 & 63659 & 66058 & 6 \\
\hline & 224767 & 219100 & 3 & & & \\
\hline & 479746 & 464990 & 3 & & & \\
\hline & 132512 & 137809 & 3 & & & \\
\hline Mean & 256570 & 246689 & & 27210 & 27674 & \\
\hline Diff. $1 \%$ & & & & & & \\
\hline
\end{tabular}

Fig. 2. Mulinia lateralis. Difference in radiolabel excretion rate over time by $\mathrm{bi}_{\mathrm{i}}$ valves expressed as percentage of incorporated radioactivity. Retention of ${ }^{35} \mathrm{~S}$ was higher than that of ${ }^{3} \mathrm{H}$. After $4 \mathrm{~h}$ bivalves retained $93.34 \pm 6.45 \%$ ( $\mathrm{n}=20)$ of ${ }^{35} \mathrm{~S}$ activity and $51.40 \pm 16.54 \%$ $(\mathrm{n}=13)$ of ${ }^{3} \mathrm{H}$ activity

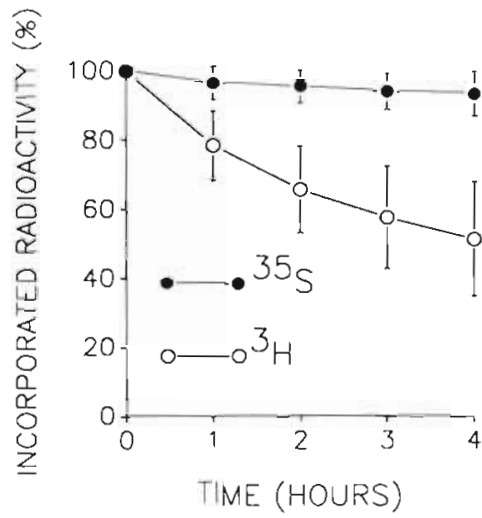

is shown in Fig. 3A, B. Particulate radioactivity decreased rapidly, with a proportional increase in dissolved excretion. A comparison between isotopes indicates that ${ }^{3} \mathrm{H}$ activity was excreted primarily in dissolved form from the beginning of the chase.

Cumulative excretion in both fractions for ${ }^{35} \mathrm{~S}$ methionine and ${ }^{3} \mathrm{H}$-thymidine after 4 chases is shown in Fig. 3C, D, respectively. When ${ }^{35} \mathrm{~S}$-methionine was used, $49.05 \pm 13.30 \%$ of excreted radioactivity was associated with particles ('feces') and 50.94 $\pm 13.30 \%$ was dissolved. The corresponding values associated with ${ }^{3} \mathrm{H}$-thymidine-labeled macromolecules were 11.43 $\pm 4.71 \%$ particulate and $88.57 \pm 4.70 \%$ dissolved

Resuspension of labeled bacteria caught on filters consistently caused the release of DOM. An average of $7.43 \pm 4.45 \%(\mathrm{n}=6)$ of ${ }^{35} \mathrm{~S}$ label and $21.08 \pm 15.78 \%$ ( $\mathrm{n}=3$ ) of ${ }^{3} \mathrm{H}$ label was released in solution during resuspension of bacteria. Preliminary experiments showed that after 2 washes $(5 \mathrm{ml}$ each), less than $0.01 \%$ of initial L- $\left[{ }^{35} \mathrm{~S}\right]$-methionine and [methyl $\left.-{ }^{3} \mathrm{H}\right]-$ thymidine activity remained bound to the filter. We attribute the release of labeled DOM $1<1 \%$ of initially added activity) to bacterial cell damage. We did not attempt to characterize these dissolved substances, and their chemical affinity remains unknown. The percentage uptake of DOM associated with both isotopes was lower than that of particulate uptake (compare Fig. 4A, B with Fig. 4C, D).

\section{DISCUSSION}

Assimilation in this study is defined as incorporated radioactivity minus radioactivity lost as excreta (particulate and dissolved; see also Bayne 1983 p. 312). The use of radiolabeled food to measure absorption and assimilation poses considerable problems of interpretation (Conover \& Francis 1973). The focus of our study was the assimilation of bacterial (particulate) radioactivity. However, we have utilized a 2-compartment 
Fig. 3. Mulinia lateralis. Difference in excreted radioactivity in particulate and dissolved fractions over time for (A) ${ }^{35} \mathrm{~S}$ and (B) ${ }^{3} \mathrm{H}$. Excreted radioactivity for ${ }^{35} \mathrm{~S}$ was close to background levels for the $4 \mathrm{~h}$ period. Also shown are cumulative radioactivity excretion after $4 \mathrm{~h}$ for $(\mathrm{C})^{35} \mathrm{~S}$ and (D) ${ }^{3} \mathrm{H}$

Fig. 4. Mulinia lateralis. Uptake of particulate-phase (bacteria) and dissolvedphase radioactivity by experimental bivalves compared to formalin-killed controls, and disappearance of radioactivity due to feeding-chamber adsorption, for (A, C) ${ }^{35} \mathrm{~S}$ and (B, D) ${ }^{3} \mathrm{H}$
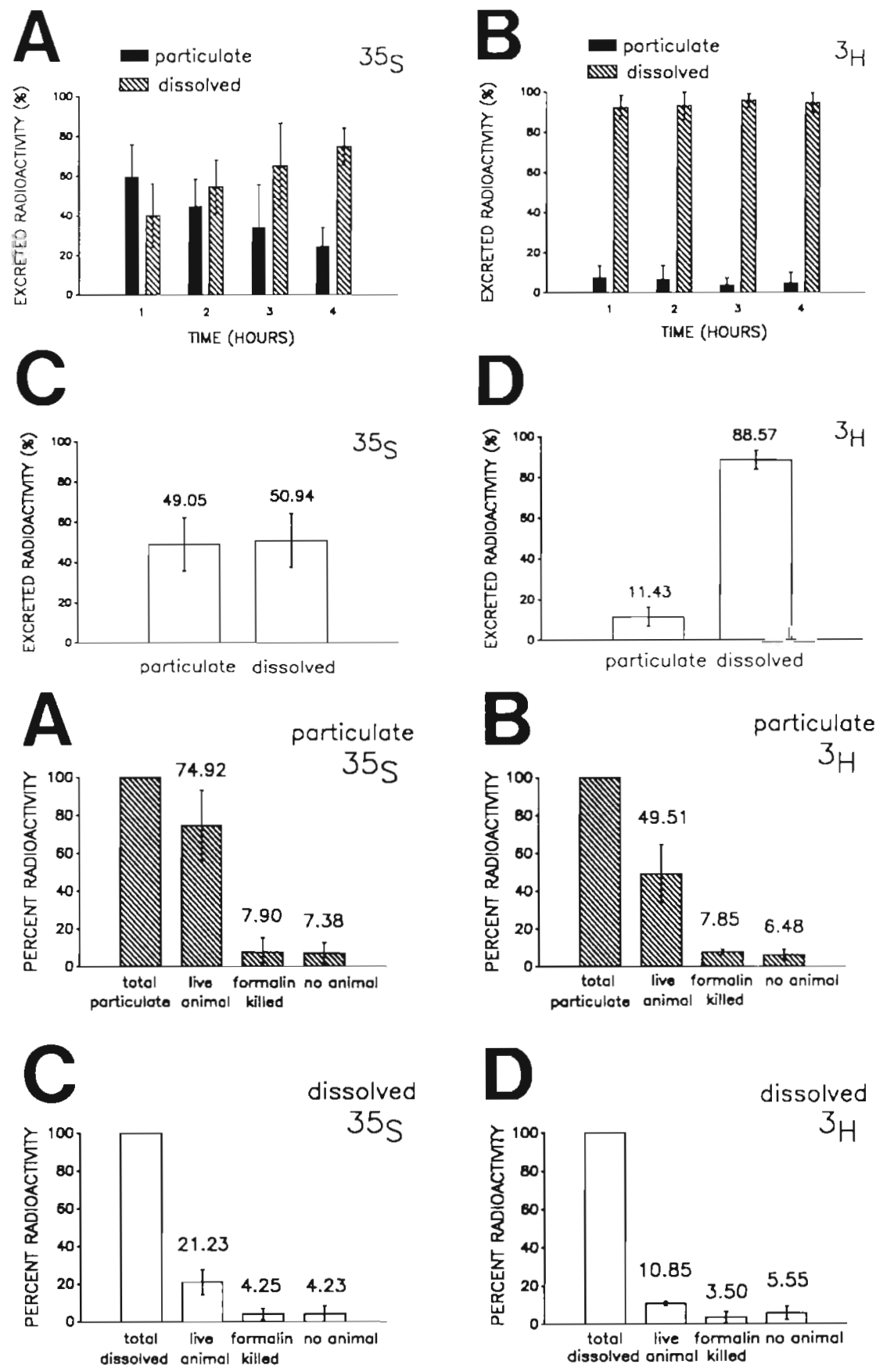

system consisting of bacteria + DOM and DOM only. Appropriate corrections for DOM were necessary (see Amouroux \& Amouroux 1988) to provide an adequate index of the ability of Mulinia lateralis to assimilate bacterioplankton. The duration of our experiments was kept short $(1 \mathrm{~h})$, to minimize recycling of radioisotopes in feeding chambers while allowing sufficient radioactivity to be incorporated for liquid scintillation counting. We adopted a closed system for our study and make no inferences as to the efficiency of bacterial clearance by $M$. lateralis in natural systems.
From our experiments, we have shown that Mulinia lateralis can clear and assimilate bacteria smaller than $1 \mu \mathrm{m}$. Assimilation efficiency estimated by using ${ }^{35} \mathrm{~S}$ methionine in this study $(93.34 \%)$ is higher than most previously reported values. Birkbeck \& McHenery (1982) utilized several cultured bacteria as food and ${ }^{3} \mathbf{H}$ and ${ }^{14} \mathrm{C}$ as tracers in their studies with Mytilus edulis $\mathrm{L}$. Assimilation estimations based on ${ }^{3} \mathrm{H}$ tracers used in their study differed depending on the labeled bacterial macromolecule. When ${ }^{3} \mathrm{H}$-thymidine was used to label DNA in bacteria, AE ranged from 7 to $36 \%$. When ${ }^{3} \mathrm{H}$ - 
diamiopimelic acid was used to label bacterial cell wall, an $A E$ of $81 \%$ was reported. An efficiency of $84 \%$ was reported for ${ }^{14} \mathrm{C}$-labeled bacterial macromolecules. Birkbeck \& McHenery (1982) were the first authors to demonstrate differential utilization of bacterial macromolecules in bivalves.

The tracer ${ }^{14} \mathrm{C}$-glucose was used by Harvey \& Luoma (1984) in their studies on Macoma balthica (L.). Assimilation efficiency reported as ${ }^{14} \mathrm{C}$ activity remaining in the bivalve's foot after $14 \mathrm{~d}$ was ca $20 \%$. Amouroux (1986) studied Venus verrucosa $\mathrm{L}$. and reported ${ }^{14} \mathrm{C}$ assimilation values between 39.9 and $51 \%$ during a $40 \mathrm{~h}$ period. Studying Crassostrea virginica (Gmelin) and using ${ }^{24} \mathrm{C}$ and ${ }^{15} \mathrm{~N}$ as tracers, Crosby et al. (1990) reported $A E$ values of 52.5 and $57.2 \%$ for bacterial carbon and nitrogen respectively.

Hollibaugh et al. (1980) were the first researchers to propose the use of ${ }^{3} \mathrm{H}$-thymidine as a tracer in bacteriafeeding studies. Using Donax gouldii Dall and Mytilus edulis as study organisms, they reported extremely high uptake values for both species after $1 \mathrm{~h}$ feeding. Average clearance rates for the 2 species used in their study were $4.6 \mathrm{ml} \mathrm{h}^{-1}$ for $D$. gouldii and $6.5 \mathrm{ml} \mathrm{h}^{-1}$ for $M$. edulis. Based on these clearance values $D$. gouldii incorporated $99.69 \%$ of cleared particulate radioactivity after $\hat{1} \mathrm{~h}$. During the same time period, $M$. edulis incorporated ca $100 \%$ of cleared particulate radioactivity. These results suggest $100 \%$ retention of naturalsized bacteria. Later studies have, however, shown that $M$. edulis and related Donax spp. are not efficient at clearing natural-sized bacteria (Wright et al. 1982, Matthews et al. 1989). We attribute the high 'assimilation' values of Hollibaugh et al. (1980) to a possible underestimation of clearance rate. Methods for estimation of clam and mussel clearance rates were not given in this pioneering study.

Direct comparison of assimilation efficiencies reported in different studies is difficult. Generally, information is not given concerning the specific bacterial components labeled. Apart from the discrepancy in choice of tracers, assimilation values are reported after variable time periods ranging from $1 \mathrm{~h}$ to $14 \mathrm{~d}$. An appropriate time period of several hours to allow for purging of unabsorbed food is necessary. Extremely long 'chase' periods, however, increase the chances of isotope recycling within the system (Conover \& Francis 1973), especially in static systems.

The discrepancy in assimilation and excretion of radiolabel between isotopes in this study can be explained by the difference in labeled moieties. Tritiated thymidine used in this study is labeled at its methyl group at the $\mathrm{C} 5$ position of thymine. The tracers ${ }^{35} \mathrm{~S}$-methionine and ${ }^{3} \mathrm{H}$-thymidine were chosen to selectively label bacterial proteins and DNA. Tritiated thymidine, however, has recently been shown to be less specific than originally proposed. Hollibaugh (1988) has demonstrated that some microbial communities incorporate up to $53 \%$ of [methyl- ${ }^{3} \mathrm{H}$ ]-thymidine into protein. [Methyl- ${ }^{3} \mathrm{H}$ ]-thymidine can be degraded rapidly within bacterial cells. The ${ }^{3} \mathrm{H}$ on the methyl group may subsequently be transferred to other compounds and incorporated by de novo pathways into RNA, DNA and proteins (Moriarty 1986). In our studies, as much as $47.75 \pm 5.32 \%$ of radioactivity associated with ${ }^{3} \mathrm{H}$ was found in hot TCA precipitated macromolecules (non-DNA) after $1 \mathrm{~h}$ incubation. Because ${ }^{3} \mathrm{H}$-methyl can enter a general $\mathrm{CH}_{3}$ pool, interpretation of its production and excretion pathways is difficult.

$\mathrm{CH}_{3}$ has many functions in cellular metabolism (Zubay 1988), making ${ }^{3} \mathrm{H}$ a non-specific label. The large portion of dissolved ${ }^{3} \mathrm{H}$ may have included a variety of substances, in particular ${ }^{3} \mathrm{H}_{2} \mathrm{O}$, a product of cellular respiration. That this dissolved ${ }^{3} \mathrm{H}$ radioactivity was not taken up by bacteria in earlier pulse-chase experiments suggests that it is not in a utilizable form for bacteria. Release of dissolved ${ }^{3} \mathrm{H}$ from digestion of labeled bacteria was first noted by Birkbeck \& McHenery (1982). These authors suggested that Mytilus edulis selectively utilized different bacterial polymers, rejecting DNA.

Methionine is classified as an essential amino acid in mammalian nutrition studies (Zubay 1988). The mineral nutrient sulfur can be absorbed either as part of amino acids or as inorganic sulfate with equal efficiency (Linder 1985). Sulfur is the site for attachment and transfer of 1-C methyl groups, via S-adenosylmethionine. It is also part of the important reducing agent, glutathione, and various important coenzymes and vitamins, inciuding coenzyme A (Linder 1985).

The ${ }^{35} \mathrm{~S}$ isotope in methionine is utilized by bivalves, specifically, in several metabolic pathways (Florkin \& Bricteux-Grégoire 1972). The few studies on interconversions of sulfur amino acids in molluscs have focused, primarily, on taurine and the methyltransferase enzymes (Bishop et al. 1983).

Allen \& Awapara (1960) and Allen \& Garrett (1972) report labeling of taurine with ${ }^{35} \mathrm{~S}$-methionine in tissues of Mya arenaria L. and Mytilus edulis. The amino acid derivative taurine is conserved to different degrees in these bivalves and functions in intracellular osmoregulation. In $M$. arenaria subjected to osmotic shock, taurine was rapidly degraded but ${ }^{35} \mathrm{~S}$ was retained within the bivalve. The extent to which taurine is synthesized and degraded in Mulinia lateralis is unknown.

For both ${ }^{35} \mathrm{~S}$ and ${ }^{3} \mathrm{H}$ the initially excreted radioactivity in particulate phase may be attributed to gut passage of unassimilated bacterial fragments. Bacterial fragments, demonstrating digestion of bacteria, have been observed in the alimentary canal of Mytilus edulis larvae by Prieur (1983). 


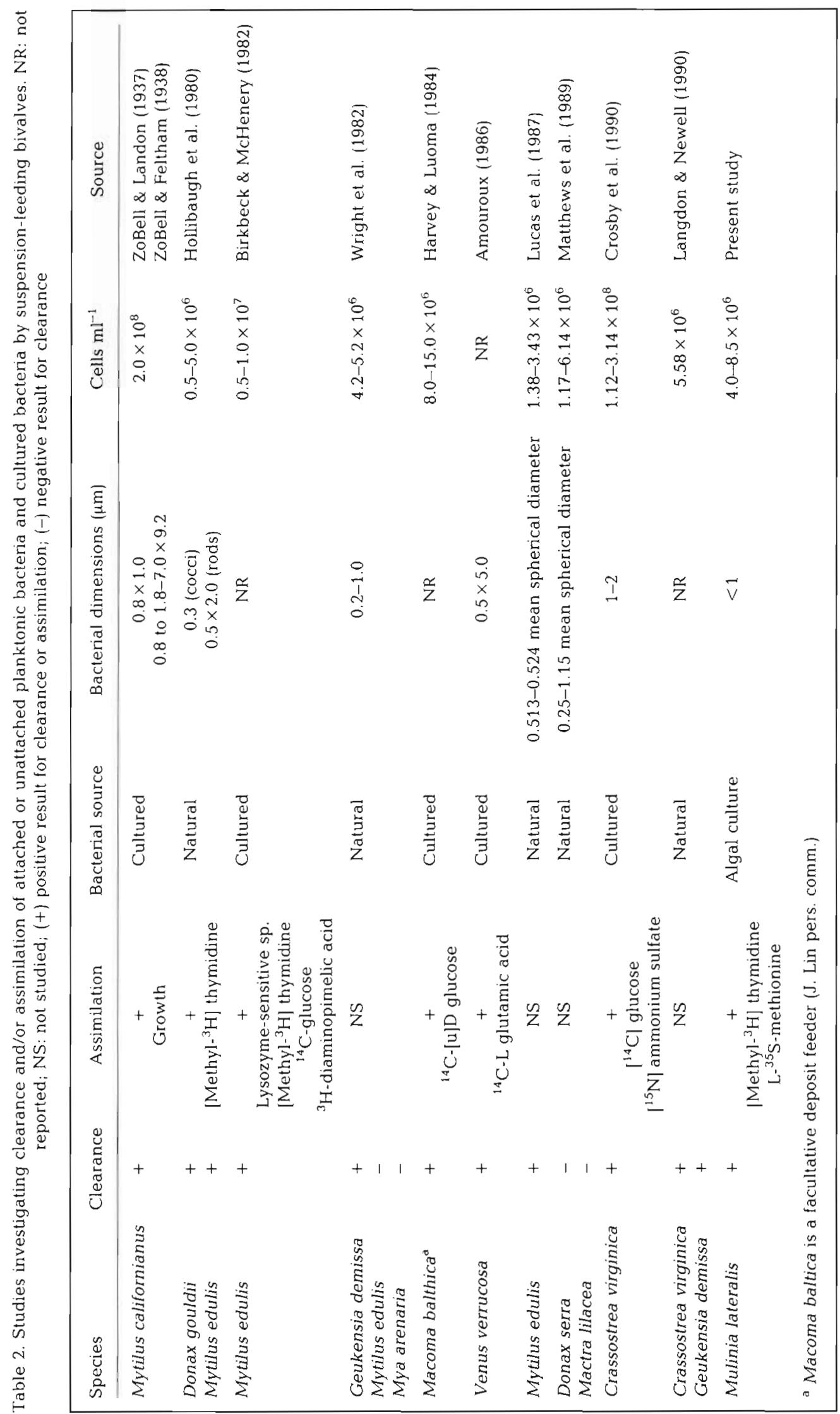


Results from our study show that approximately half of the excreted ${ }^{35} \mathrm{~S}$ label was recovered in dissolved form. Dissolved ${ }^{35} \mathrm{~S}$-labeled compounds were also found by Allen \& Awapara (1960) and Allen \& Garrett $(1972)$ in their studies using ${ }^{35} \mathrm{~S}$-methionine. Using ${ }^{14} \mathrm{C}$ glutamic acid as a tracer, Amouroux (1986) detected radioactivity associated with unidentified DOM in his studies on Venus verrucosa. Based on previous studies, the dissolved ${ }^{35} \mathrm{~S}$ could have resulted from bacterial degradation of fecal material, as suggested by Amouroux \& Amouroux (1988), or from excretion of dissolved $\mathrm{SO}_{4}{ }^{-2}$ (Linder 1985, Allen \& Garrett 1972). Activity from ${ }^{35} \mathrm{~S}$ caught on filters ('particulate') during later parts of the chase may have been that incorporated into sulfonated mucopolysaccarides, a major component of molluscan mucus (Allen \& Garrett 1972).

The ability of bivalves to effectively clear and assimilate bacteria-sized particles seems to be speciesspecific (Table 2). Comparative particle-retention studies in bivalves indicate that particles smaller than 2 to $4 \mu \mathrm{m}$ are not cleared efficiently (Møhlenberg \& Riisgård 1978, Riisgård 1988). These studies are, however, based on particle counts using electronic particle counters which cannot routinely detect particles $<2 \mu \mathrm{m}$. Although clearance of larger particles may be high, clearance of nano- and picoplankton-sized particles may have been underestimated.

In this study, we have utilized 'natural'-sized bacteria to estimate $A E$ in Mulinia lateralis. Many previous researchers investigating assimilation of marine bacteria by bivalves have relied on radiolabeled bacteria grown on enriched organic media (Birkbeck \& McHenery 1982, Harvey \& Luoma 1984, Amouroux 1986). Cultured marine bacteria are known to be much larger than natural forms (Lee \& Fuhrman 1987). Therefore, use of large bacteria may overestimate the contribution of bacteria to bivalve nutrition.

To estimate bacterial contribution to bivalve nutrition, investigators should also use bacterial numbers commensurate with what their species of interest might encounter in natural systems. In early studies, ZoBell \& Landon (1937) and ZoBell \& Feltham (1938) demonstrated growth in Mytilus californianus Conrad using high concentrations of cultured bacteria $\left(2.0 \times 10^{8}\right.$ to $5.0 \times 10^{9}$ cells $\left.\mathrm{ml}^{-1}\right)$. There have been no recent studies documenting growth in adult bivalves fed natural bacteria.

Clearance and assimilation of free-living bacteria by bivalves demonstrates the potential of these particles as sources of nutrition (Seiderer et al. 1984, Crosby et al. 1990, Langdon \& Newell 1990). Bacterioplankton also play an important role in the mediation of nutrients from detritus. The role of bacteria in mediating the utilization of refractory carbon and nitrogen from detrital complexes has been documented by many authors
(Stuart et al. 1982, Newell \& Field 1983, Seiderer et al. 1984, Benner et al. 1988, Crosby et al. 1990). Compared with other planktonic components, natural planktonic bacteria have a lower C:N ratio (Nagata 1986, Lee \& Fuhrman 1987). Nitrogen and crude protein content in bacteria can be as high as 12.5 and $78 \%$ respectively (Young \& Scrimshaw 1975).

Although the contribution of bacterial carbon and nitrogen to bivalve nutrition has been well documented, little information exists on the contribution of specific bacterial macromolecules. The degradation of methionine and high retention of ${ }^{35} \mathrm{~S}$ found in this study suggest a potentially important role of bacteria as a source of mineral nutrients, as well as proteins, for Mulinia lateralis. Caution in isotope selection for use in bacteria-assimilation studies is recommended. The importance of bacteria as a food source is dependent upon both bacterial quantity and quality.

Acknowledgements. We thank Drs S. K. Allen and J. Scarpa for supplying specimens of Mulinia lateralis. We also thank Drs S. R. Fegley, R. G. Gustafson, J. N. Kraeuter, B. A. MacDonald and S. C. Wainright, and Mr D. Bushek and Mr W. J. Canzonier, for critically reading the manuscript. Dr S. E. Ford and Ms H. L. Motto assisted in figure preparation. Com. ments from 2 anonymous reviewers helped improve the manuscript. K. Chalermwat is under scholarship from the Royal Thai Government. This is New Jersey Agricultural Experiment Station Publication no. D-32406-2-90 and Contribution no. 90-41 of the Institute of Marine and Coastal Sciences, Rutgers University, supported by New Jersey State funds and the Fisheries and Aquaculture Technology Extension Center.

\section{LITERATURE CITED}

Allen, J. A. Garrett, M. R. (1972). Studies on taurine in the euryhaline bivalve, Mya arenaria. Comp. Biochem. Physiol. 41A: 307-317

Allen, K., Awapara, J. (1960). Metabolism of sulfur amino acids in Mytilus edulis and Rangia cuneata. Biol. Bull. mar. biol. Lab., Woods Hole 118: 173-182

Amouroux, J. M. (1986). Comparative study of the carbon cycle in Venus verrucosa fed on bacteria and phytoplankton. 1. Consumption of bacteria (Lactobacillus sp.). Mar Biol. 90: 237-241

Amouroux, J. M., Amouroux, J. (1988). Comparative study of the carbon cycle in Venus verrucosa fed on bacteria and phytoplankton. III. Comparison of models. Mar. Biol. 97: 339-347

Bayne, B. L. (1983). Physiological ecology of marine molluscan larvae. In: Verdonk, N. H., van den Biggelaar, J. A. M., Tompa, A. S. (eds.) The Mollusca, Vol. 3, Development. Academic Press, New York, p. 299-343

Benner, R., Lay, J., K'nees, E., Hodson, R. E. (1988). Carbon conversion effciency for bacterial growth on lignocellulose: implications for detritus-based food webs. Limnol. Oceanogr. 33: 1514-1526

Birkbeck, T H., McHenery, J. G. (1982). Degradation of bacteria by Mytilus edulis. Mar Biol. 72: 7-15

Bishop, S. H., Ellis, L. L., Burcham, J. M. (1983). Amino acid 
metabolism in molluscs. In: Hochachka, P. W., Wilbur, K. M. (eds.) The Mollusca, Vol. 1, Metabolic biochemistry and molecular biomechanics. Academic Press, New York, p. $243-327$

Conover, R. J., Francis, V (1973). The use of radioactive isotopes to measure the transfer of materials in aquatic food chains. Mar. Biol. 18: 272-283

Crosby, M. P., Newell, R. I. E., Langdon, C. J. (1990). Bacterial mediation in the utilization of carbon and nitrogen from detrital complexes by Crassostrea virginica. Limnol. Oceanogr. 35: 625-639

Florkin, M., Bricteux-Grégoire, S. (1972). Nitrogen metabolism in mollusks. In: Florkin, M., Scheer, B. T. (eds.) Chemical zoology, Vol. 7. Academic Press, New York, p. 301-348

Harvey, R. W., Luoma, S. N. (1984). The role of bacterial exopolymer and suspended bacteria in the nutrition of the deposit-feeding clam, Macoma balthica. J. mar. Res. 42: 957-968

Hobbie, J. E., Daley, R. J., Jasper, S. (1977). Use of nuclepore filters for counting bacteria by epifluorescence microscopy. Appl. environ. Microbiol. 33: 1225-1228

Hollibaugh, J. T. (1988). Limitations of the $\left[{ }^{3} \mathrm{H}\right]$ thymidine method for estimating bacterial productivity due to thymidine metabolism. Mar. Ecol. Prog. Ser. 43: 19-30

Hollibaugh, J. T., Fuhrman, J. A., Azam, F. (1980). Radioactive labeling of natural assemblages of bacterioplankton for use in trophic studies. Limnol. Oceanogr. 25: 172-181

Jamieson, T., Wardlaw, A. C. (1989). Degradation of bacterial lipopolysaccarides by digestive-gland extracts of marine bivalve molluscs. Comp. Biochem. Physiol. 94B: 837-843

Kemp, P. F., Newell, S. Y., Krambeck, C. (1990). Effects of filter-feeding by the ribbed mussel Geukensia demissa on the water-column microbiota of a Spartina alterniflora saltmarsh. Mar. Ecol. Prog. Ser. 59: 119-131

Langdon, C. J., Newell, R. I. E. (1990). Utilization of detritus and bacteria as food sources by two bivalve suspension feeders, the oyster Crassostrea virginica and the mussel Geukensia demissa. Mar. Ecol. Prog. Ser. 58: 299-310

Lee, S., Fuhrman, J. A. (1987). Relationships between biovolume and biomass of naturally derived marine bacterioplankton. Appl. environ. Microbiol. 53: 1298-1303

Levinton, J. S. (1970). The paleoecological significance of opportunistic species. Lethaia 3: 69-78

Linder, M. C. (1985). Nutrition and metabolism of the major minerals. In: Linder, M. C. (ed.) Nutritional biochemistry and metabolism: with clinical applications. Elsevier, New York, p. 133-149

Lucas, M. I., Newell, R. C., Shumway, S. E., Seiderer, L. J., Bally, R. (1987). Particle clearance and yield in relation to bacterioplankton and suspended particulate availability in estuarine and open coast populations of the mussel Mytilus edulis. Mar. Ecol. Prog. Ser. 36: 215-224

Matthews, S., Lucas, M. I., Stenton-Dozey, J. M. E., Brown, A. C. (1989). Clearance and yield of bacterioplankton and particulates for two suspension-feeding infaunal bivalves,

This article was presented by S. Y. Newell, Sapelo Island, Georgia, USA
Donax serras Röding and Mactra lilacea Lam. J. exp. mar. Biol. Ecol. 125: 219-234

McHenery, J. G., Birkbeck, T H. Allen, J. A. (1979). The occurrence of lysozyme in marine bivalves. Comp. Biochem. Physiol. 63B: 25-28

Møhlenberg, F., Riisgård, H. U. (1978). Efficiency of particle retention in 13 species of suspension feeding bivalves. Ophelia 17: 239-246

Moriarty, D. J. W. (1986). Measurement of bacterial growth rates in aquatic systems from rates of nucleic acid synthesis. Adv. microb. Ecol. 9: 245-292

Nagata, T. (1986). Carbon and nitrogen content of natural planktonic bacteria. Appl. environ. Microbiol. 52: 28-32

Newell, R. C., Field, J. G. (1983). The contribution of bacteria and detritus to carbon and nitrogen flow in a benthic community. Mar. Biol. Lett. 4: 23-36

Prieur, D. (1983). Ingestion et digestion de bactéries par les larves de la moule, Mytilus edulis. J. mollusc. Stud. 12A: 149-153

Riisgărd, H. U. (1988). Efficiency of particle retention and filtration rate in 6 species of Northeast American bivalves. Mar. Ecol. Prog. Ser. 45: 217-223

Santos, S. L., Simon, J. L. (1980). Response of soft-bottom benthos to annual catastrophic disturbance in a South Florida estuary. Mar. Ecol. Prog. Ser. 3: 347-355

Seiderer, L. J., Davis, C. L., Robb, F. T., Newell, R. C. (1984). Utilization of bacteria as nitrogen resource by kelp-bed mussel Choromytilus meridionalis. Mar Ecol. Prog. Ser. 15: 109-116

Shumway, S. E. (1983). Factors affecting oxygen consumption in the coot clam Mulinia lateralis (Say). Ophelia 22: 143-171

Shumway, S. E., Newell, R. C. (1984). Energy resource allocation in Mulinia lateralis (Say), an opportunistic bivalve from shallow water sediments. Ophelia 23: 101-118

Stuart, V., Field, J. G., Newell, R. C. (1982). Evidence for absorption of kelp detritus by the ribbed mussel Aulacomya ater using a new ${ }^{51} \mathrm{Cr}$-labeled microsphere technique. Mar. Ecol. Prog. Ser. 9: 263-271

Wikner, J., Andersson, A., Nonnark, S., Hagström, A. (1986) Use of genetically marked minicells as a probe in measurement of predation on bacteria in aquatic environments. Appl. environ. Microbiol. 52: 4-8

Wright, R. T., Coffin, R. B., Ersing, C. P., Pearson, D. (1982). Field and laboratory measurements of bivalve filtration of natural marine bacterioplankton. Limnol. Oceanogr. 27: 91-98

Young, V. R., Scrimshaw, N. S. (1975). Clinical studies on the nutritional value of single-cell proteins. In: Tannenbaum, S. R., Wang, D. I. C. (eds.) Single-cell Protein II. MIT Press, Cambridge, Massachusetts, p. 564-586

ZoBell, C. E., Feltham, C. B. (1938). Bacteria as food for certain marine invertebrates. J. mar. Res. 1: 312-327

ZoBell, C. E., Landon, W. A. (1937). Bacterial nutrition of the California mussel. Proc. Soc. exp. Biol. Med. 36: 607-609

Zubay, G. (1988). Biochemistry. MacMillan Publishing Company, New York

Manuscript first received: November 5, 1990

Revised version accepted: January 16, 1991 